\title{
尿毒素による腎・血管障害と向血栓傾向
}

丹羽利充*

\section{Uremic toxin-induced nephro-vascular injury and thrombophilia}

\author{
Toshimitsu NIWA
}

\begin{abstract}
要約：慢性腎臟病 $(\mathrm{CKD})$ 患者では心血管疾患 $(\mathrm{CVD})$ の発症率および死亡率が高くなり，心腎連関 といわれている，CKDが進行すると血中に尿毒素が蓄積してくる，尿毒素であるインドキシル硫 酸は腎障害を進行させるのみでなく心血管障害をきたす。また CKD 患者ではステント血栓が起こ りやすいなど向血栓傾向がみられる，インドキシル硫酸は血管内皮細胞，血管平滑筋細胞，末梢 血単核球において組織因子の発現を光進させる。 さらにCKD 患者の血中組織因子濃度は血漿イン ドキシル硫酸濃度と正相関している. CKD の進行期では血中に蓄積しているインドキシル硫酸が 血管細胞の組織因子の発現を充進させ, 向血栓傾向をきたしている可能性が示唆されている.
\end{abstract}

Key words: uremic toxins, indoxyl sulfate, chronic kidney disease, cardiovascular disease, thrombophilia

\section{1.はじめに}

慢性腎臓病 $(\mathrm{CKD})$ 患者では, 心不全, 心筋梗塞お よび脳卒中などの心血管疾患 $(\mathrm{CVD})$ の発症率およ び死亡率が高くなる，CKDにおいて CVDの合併頻 度が高い理由として，両者の危険因子の多くは共通 であること，さらに貧血および尿毒素などの CKD に特有な病態の寄与が考えられている。尿毒素であ るインドキシル硫酸は心血管障害作用を示し CVD の進行に関与していると考えられている.

尿毒素は, 1) 遊離水溶性低分子量物質 (分子量 500 未満), 2) タンパク結合物質, 3) 中分子量物質(分 子量 500～60000）に大きく分けられる. タンパク結 合物質は，血中ではアルブミンと結合しているため 透析によって除去されにくい. そのため, 透析患者 における種々の合併症の発症に関与していると考え られる。タンパク結合物質であるインドキシル硫酸 はCKDの進行促進作用を示し，最近ではCVDの 進行にも関与していることが明らかにされ, 心腎連

*責任者連絡先：

修文大学健康栄養学部

T 491-0938 愛知県一宮市日光町 6 番地

Tel/Fax: 0586-43-3114

E-mail: tniwa@med.nagoya-u.ac.jp
関のキープレイヤーと考えられている.

\section{2. 尿毒素としてのインドキシル硫酸}

経口的に摂取したタンパク質が大腸内で加水分解 され生成したトリプトファンが，大腸菌などにより インドールに代謝される。インドールは腸管から吸 収され肝臓で酸化, 硫酸抱合されインドキシル硫酸 となって血中に放出される。正常では血中のインド キシル硫酸は腎臓から尿中に排泄される。腎不全で はインドキシル硫酸のクリアランスが低下し血清 インドキシル硫酸濃度は著明に増加する ${ }^{1,2)}$. 血中 では約 95\%がアルブミンと結合しており血液透析 によって除去されにくく，血液透析による減少率は 約 30\% と低い. 経口吸着薬(AST-120) はインドキシ ル硫酸の前駆体であるインドールを腸内で吸着する ことにより, 血清インドキシル硫酸濃度を低下させ る $(\text { 図 } \mathbf{1})^{3)}$.

\section{3. インドキシル硫酸による腎障害}

腎不全ラットにインドキシル硫酸，インドールを 投与すると腎不全がより進行することから，インド キシル硫酸は腎不全の進行を促進する尿毒素であ 


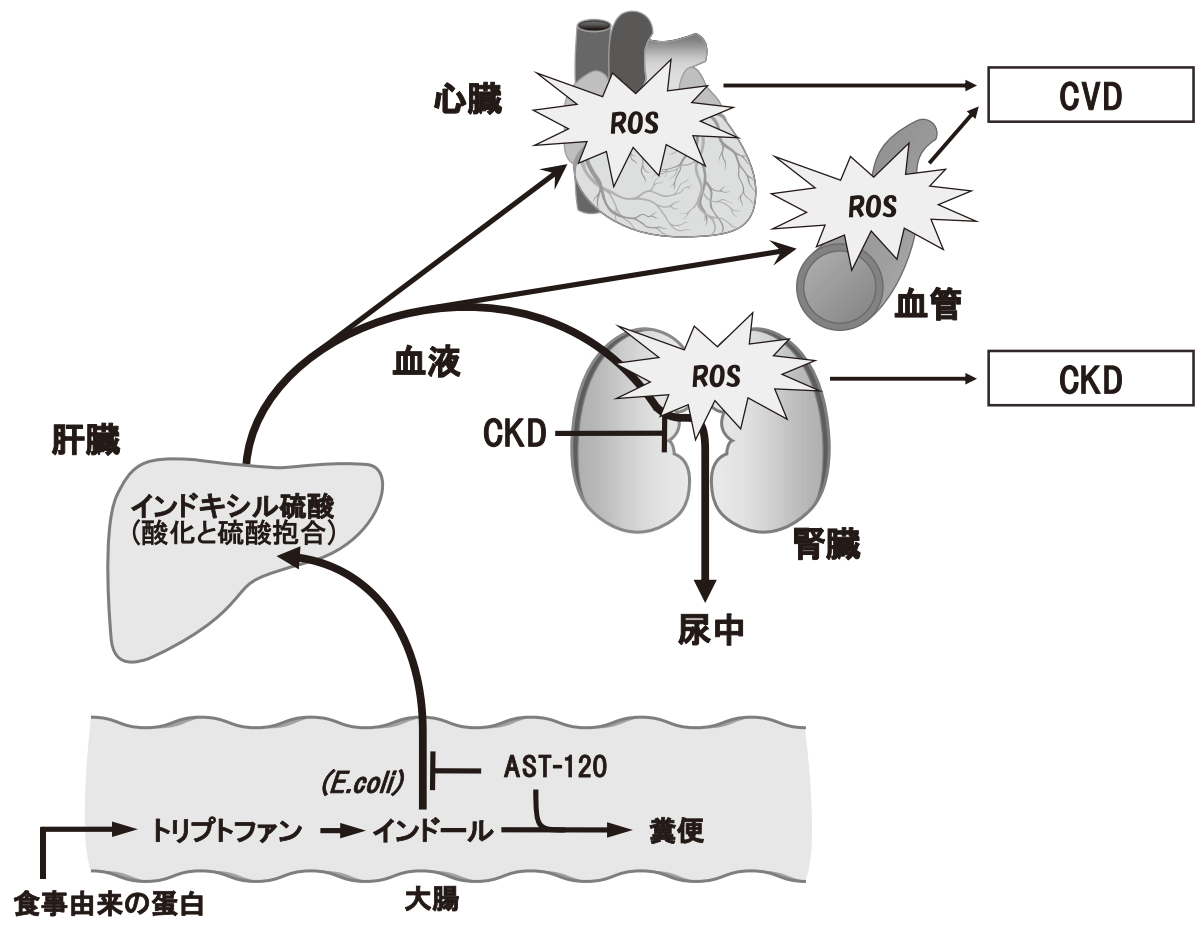

図 1 インドキシル硫酸の代謝経路と経口吸着薬(AST-120)の作用点

$ろ^{1-3)}$ ．インドキシル硫酸はトランスフォーミング増 殖因子 (TGF)- $\beta 1$, メタロプロテアーゼ組織インヒ ビター(TIMP) -1，プロ $\alpha 1$ (I)コラーゲンの発現を増 加させ腎臓の間質線維化や糸球体硬化をきたす4). インドキシル硫酸は有機アニオントランスポーター （OAT1，OAT3）を介して近位尿細管細胞に蓄積し ${ }^{5)}$, 活性酸素種 (ROS) の産生と抗酸化系の障害により尿 細管細胞障害をきたし，間質の線維化を促進する (図 2) ${ }^{6}$.

インドキシル硫酸は糸球体メサンギウム細胞にお ける NADPH オキシダーゼを活性化して，スーパー オキシドなどの ROS を増加させる。ささらにインド キシル硫酸は腎臓における抗酸化酵素であるスー パーオキシドジスムターゼの活性を低下させる7).

インドキシル硫酸は近位尿細管細胞において ROS の誘導, NF-KB の活性化, p53の発現を介して, 細 胞老化と線維化の促進, 細胞増殖の抑制をきたし, 腎不全の進展を促進する ${ }^{8,9)}$ 。またインドキシル硫 酸は，尿細管細胞の上皮一間葉形質転換 $(\mathrm{EMT})$ をき たし，腎線維化を促進する ${ }^{10)}$ ，インドキシル硫酸は 尿細管細胞による単球走化誘導蛋白 (MCP-1) 発現を 促進する ${ }^{11}$ 。ささらインドキシル硫酸は近位尿細管
細胞において STAT3 のリン酸化を介して MCP-1, TGF- $\beta 1$ ，平滑筋アクチン (SMA)の発現， NF-kB の 活性化，細胞老化を促進する ${ }^{12)}$.

またインドキシル硫酸は腎臓における Klothoの 発現を減少させ，細胞老化を促進する ${ }^{13)}$ 。 その機序 として，インドキシル硫酸は，近位尿細管細胞にお いて ROS 産生と NF-kB の活性化により Klotho 発 現を低下させる9).

\section{4. インドキシル硫酸による心血管障害}

インドキシル硫酸は酸化ストレスを充進し，血管 平滑筋細胞増殖や大動脈石灰化，血管内皮細胞障 害，心筋細胞の肥大化など CVD，さらに骨代謝異 常とも関連している $(\text { 図 3 })^{14)}$.

インドキシル硫酸を高血圧ラットに経口投与する と大動脈の石灰化，壁肥厚，および細胞老化を促進 する ${ }^{15)}$ ．インドキシル硫酸は血管平滑筋細胞におけ る NADPH オキシダーゼを活性化して ROS 産生を 増加させ骨芽細胞への分化，および増殖を促進す る ${ }^{16,17)}$ 。またインドキシル硫酸は血管平滑筋細胞に おいて ROS 産生を増加させ, p53, p21，プレラミン 


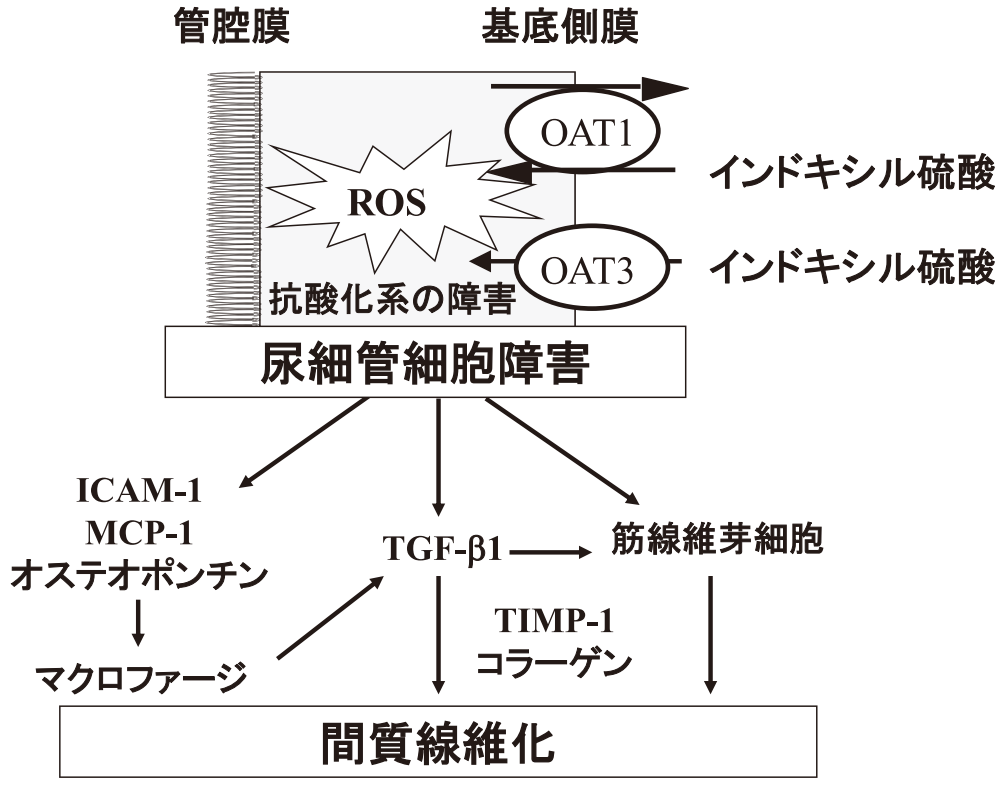

図 2 インドキシル硫酸による ROS 産生と腎尿細管細胞障害・間質線 維化の促進

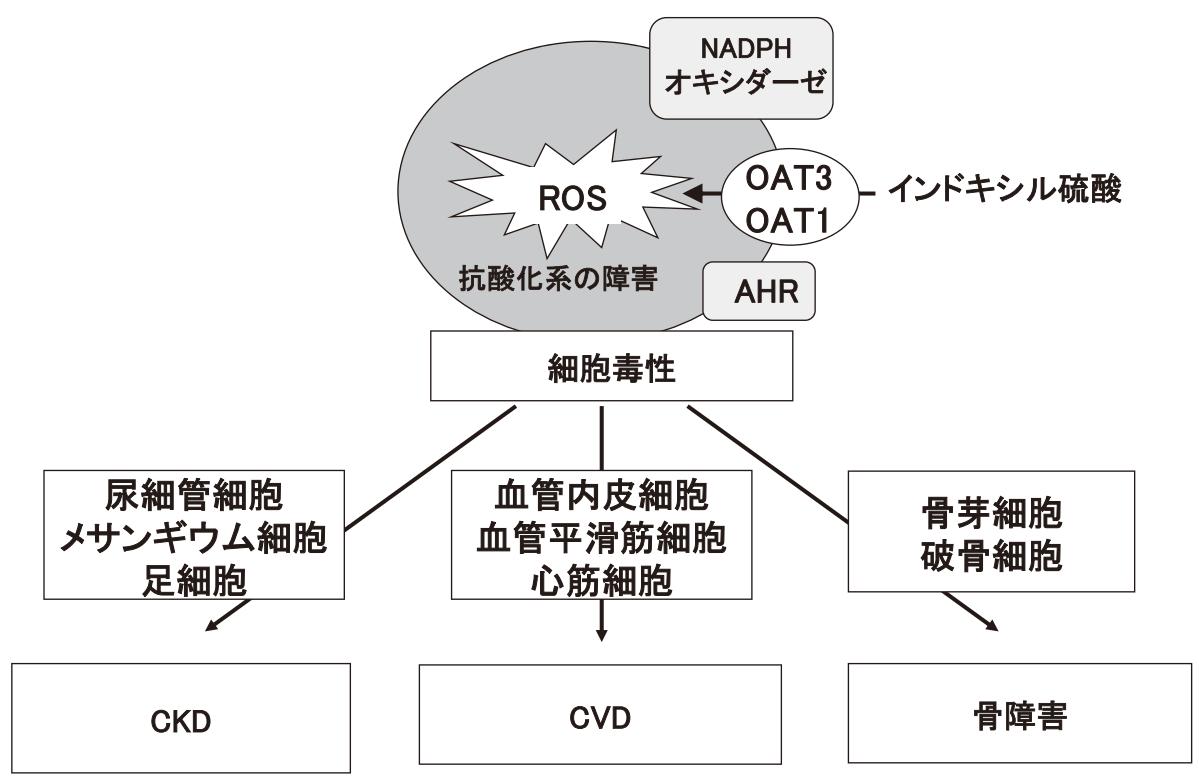

図 3 インドキシル硫酸による細胞障害と臓器障害

A どの老化関連タンパク質の発現を立進し, 細胞 老化を促進する ${ }^{18)}$.

インドキシル硫酸は血管内皮細胞における NADPH オキシダーゼの Nox4を活性化してスーパー オキシドなどの ROS を増加させ，NO生成を減少さ せる ${ }^{19)}$ ，経口吸着薬はインドキシル硫酸の血清濃度 を下げて血管内皮細胞における ROS 産生を抑制し,
腎不全における血中の酸化ストレスを軽減する.

さらにインドキシル硫酸は，血管内皮細胞におい て ROS 産生と NF-kB の活性化を介して, MCP-1, 細胞間接着因子 (ICAM-1)の産生を増加させる ${ }^{20)}$ 。し たがって，インドキシル硫酸は血管壁への単球の浸 潤を元進し，動脈硬化を促進する。またインドキシ ル硫酸は血管内皮細胞の老化を促進する ${ }^{21)}$ 。さらに 
インドキシル硫酸は内皮細胞の接着結合を阻害す る。またインドキシル硫酸は血管内皮細胞および血 管平滑筋細胞において IL-6 の発現を立進した ${ }^{22)}$.

インドキシル硫酸は心筋細胞の肥大，心臓線維芽 細胞のコラーゲン産生，および単核球による腫瘍壊 死因子 (TNF) - $\alpha, \quad$ インターロイキン (IL) - $6, \quad$ IL-1 $\beta$ の産生増加により心臓毒性を示す ${ }^{23)}$ 。 また OAT1, OAT3 のアンタゴニストはインドキシル硫酸による 心臓のリモデリングを抑制した ${ }^{24)}$.

インドキシル硫酸はNADPH オキシダーゼの Nox4 を活性化し, ROS を誘導し, NF-KB を活性化し, p53 どの老化関連遺伝子を誘導し，腎臓と血管の 細胞老化を促進し， CKDの進行のみでなく CVDの 進行も促進する ${ }^{25)}$.

CKD 患者において, 血清インドキシル硫酸濃度 は大動脈石灰化および脈波伝播速度 $(\mathrm{PWV})$ と正相 関を示し，インドキシル硫酸濃度高值群では総死亡 率，CVD死亡率が高かった ${ }^{26)}$ 。つまり，インドキ シル硫酸は CKD 患者における CVD と高死亡率に 関与していた

冠状動脈疾患患者において血清インドキシル硫酸 濃度の高值群では頸動脈内膜中膜厚 (IMT)が有意に 高かった ${ }^{27)}$.

インドキシル硫酸は，環境毒として知られている ダイオキシンのレセプターである芳香族炭化水素受 容体 (AHR)の内因性のアゴニストであることが明 らかになった ${ }^{28)}$ 。つまり, インドキシル硫酸は, 内 因性ダイオキシン様毒素として AHR を介して種々 の臓器に毒性を示すと考えられる.

\section{5. インドキシル硫酸による向血栓傾向}

腎不全患者においては向血栓傾向があることが知 られている。腎不全患者では冠動脈インターベン ションの後にステント血栓がおきやすい. ステント 血栓が拈きやすい理由として，腎不全患者血清中の 尿毒素，とくにインドキシル硫酸が血管平滑筋に作 用して組織因子の発現を克進させ，さらに組織因子 のユビキチン化を抑制することにより組織因子を安 定化させることが考えられている291.

インドキシル硫酸は血管内皮細胞や末梢単核細胞 において，AHR を活性化させることにより組織因
子の発現を立進させた ${ }^{30)}$. CKD 患者の血中組織因 子濃度は血漿インドキシル硫酸濃度と正相関してい た。

血管平滑筋細胞において，インドキシル硫酸は OAT3を介して取り込まれ，AHR と NF- $\mathrm{KB}$ を活性 化し，（プロ）レニン受容体とプロレニンの発現を立 進させて, 細胞増殖を促進し, 組織因子の発現を増 加させることが明らかとなった ${ }^{311}$.

\section{6. おわりに}

CKD に合併するCVDにおけるインドキシル硫酸 などの尿毒素の役割が明らかにされてきた。インド キシル硫酸は腎障害作用のみでなく，心血管障害作 用を示し，さらに組織因子を発現させ向血栓傾向を きたす。インドキシル硫酸は経口吸着薬 (AST-120) によって除去可能である。経口吸着薬は CKD 患者 において，CKDのみでなく CVDの進行を抑制し, 向血栓傾向を改善することが期待される。

著者の利益相反 $(\mathrm{COI})$ の開示 :

本論文発表内容に関連して開示すべき企業との利益 相反なし

\section{文献}

1) Niwa $T$, Ise M: Indoxyl sulfate, a circulating uremic toxin, stimulates the progression of glomerular sclerosis. J Lab Clin Med 124: 96-104, 1994.

2) Niwa T, Ise M, Miyazaki T: Progression of glomerular sclerosis in experimental uremic rats by administration of indole, a precursor of indoxyl sulfate. Am J Nephrol 14: 207-212, 1994.

3) Niwa $T$, Nomura $T$, Sugiyama S, Miyazaki T, Tsukushi S, Tsutsui S: The protein metabolite hypothesis, a model for the progression of renal failure: An oral adsorbent lowers indoxyl sulfate levels in undialyzed uremic patients. Kidney Int 52: S23-S28, 1997.

4) Miyazaki $T$, Ise $M$, Seo $H$, Niwa T: Indoxyl sulfate increases the gene expressions of TGF- $\beta_{1}$, TIMP- 1 and pro $\alpha(\mathrm{I})$ collagen in uremic rat kidneys. Kidney Int 52: S15-S22, 1997.

5) Enomoto A, Takeda M, Tojo A, Sekine T, Cha SH, Khamdang S, Takayama F, Aoyama I, Nakamura S, Endou H, Niwa T: Role of organic anion transporters in the tubular transport of indoxyl sulfate and the induction of its nephrotoxicity. J Am Soc Nephrol 13: 1711-1720, 2002.

6) Taki K, Nakamura S, Miglinas M, Enomoto A, Niwa T: Accumulation of indoxyl sulfate in OAT1/3-positive tubular cells in kidneys of patients with chronic renal failure. J Ren 
Nutr 16: 199-203, 2006.

7) Owada S, Goto S, Bannai K, Hayashi H, Nishijima F, Niwa T: Indoxyl sulfate reduces superoxide scavenging activity in the kidneys of normal and uremic rats. Am J Nephrol 28: 446454, 2008.

8) Shimizu H, Bolati D, Adijiang A, Enomoto A, Nishijima F, Dateki M, Niwa T: Senescence and dysfunction of proximal tubular cells are associated with activated p53 expression by indoxyl sulfate. Am J Physiol, Cell Physiol 299: C1110-1117, 2010.

9) Shimizu H, Bolati D, Adijiang A, Adelibieke Y, Muteliefu G, Enomoto A, Higashiyama Y, Higuchi Y, Nishijima F, Niwa T: Indoxyl sulfate downregulates renal expression of Klotho through production of ROS and activation of nuclear factor- $\kappa$ B. Am J Nephrol 33: 319-324, 2011.

10) Bolati D, Shimizu H, Higashiyama $Y$, Nishijima F, Niwa T: Indoxyl sulfate induces epithelial-to-mesenchymal transition in rat kidneys and human proximal tubular cells. Am J Nephrol 34: 318-323, 2011.

11) Shimizu H, Bolati D, Higashiyama $Y$, Nishijima F, Shimizu K, Niwa T: Indoxyl sulfate upregulates renal expression of MCP-1 via production of ROS and activation of NF- $\mathrm{KB}, \mathrm{p} 53$, ERK, and JNK in proximal tubular cells. Life Sci 90: 525530, 2012.

12) Shimizu H, Yisireyili M, Nishijima F, Niwa T: Stat3 contributes to indoxyl sulfate-induced inflammatory and fibrotic gene expression and cellular senescence. Am J Nephrol 36: 184-189, 2012.

13) Adijiang A, Shimizu H, Higuchi Y, Nishijima F, Niwa T: Indoxyl sulfate reduces Klotho expression and promotes senescence in the kidneys of hypertensive rats. J Ren Nutr 21: 105-109, 2011.

14) Niwa T: Indoxyl sulfate is a nephro-vascular toxin. J Ren Nutr 20: S2-S6, 2010.

15) Adijiang A, Goto S, Uramoto S, Nishijima F, Niwa T: Indoxyl sulphate promotes aortic calcification with expression of osteoblast-specific proteins in hypertensive rats. Nephrol Dial Transplant 23: 1892-1901, 2008.

16) Muteliefu G, Enomoto A, Jiang P, Takahashi M, Niwa T: Indoxyl sulphate induces oxidative stress and the expression of osteoblast-specific proteins in vascular smooth muscle cells. Nephrol Dial Transplant 24: 2051-2058, 2009.

17) Muteliefu G, Enomoto A, Niwa T: Indoxyl sulfate promotes proliferation of human aortic smooth muscle cells by inducing oxidative stress. J Ren Nutr 19: 29-32, 2009.

18) Muteliefu G, Shimizu H, Enomoto A, Nishijima F, Takahashi M, Niwa T: Indoxyl sulfate promotes vascular smooth muscle cell senescence with upregulation of p53, p21, and prelamin A through oxidative stress. Am J Physiol, Cell Physiol 303: C126-134, 2012.

19) Tumur Z, Niwa T: Indoxyl sulfate inhibits nitric oxide production and cell viability by inducing oxidative stress in vascular endothelial cells. Am J Nephrol 29: 551-557, 2009.

20) Tumur Z, Shimizu H, Enomoto A, Miyazaki H, Niwa T: Indoxyl sulfate upregulates expression of ICAM-1 and MCP-1 by oxidative stress-induced NF- $\kappa \mathrm{B}$ activation. Am J Nephrol 31: 435-441, 2010.

21) Adelibieke Y, Shimizu H, Muteliefu G, Bolati D, Niwa T: Indoxyl sulfate induces endothelial cell senescence by increasing reactive oxygen species production and p53 activity. J Ren Nutr 22: 86-89, 2012.

22) Adelibieke $Y$, Yisireyili M, Ng HY, Saito S, Nishijima F, Niwa T: Indoxyl sulfate induces IL-6 expression in vascular endothelial and smooth muscle cells through OAT3-mediated uptake and activation of AhR/NF- $\kappa \mathrm{B}$ pathway. Nephron Exp Nephrol 128: 1-8, 2014.

23) Lekawanvijit S, Adrahtas A, Kelly DJ, Kompa AR, Wang BH, Krum H: Does indoxyl sulfate, a uraemic toxin, have direct effects on cardiac fibroblasts and myocytes? Eur Heart J 31: 1771-1779, 2010.

24) Liu S, Wang BH, Kompa AR, Lekawanvijit S, Krum H: Antagonists of organic anion transporters 1 and 3 ameliorate adverse cardiac remodelling induced by uremic toxin indoxyl sulfate. Int J Cardiol 158: 457-458, 2012.

25) Niwa $T$, Shimizu H: Indoxyl sulfate induces nephrovascular senescence. J Ren Nutr 22: 102-106, 2012.

26) Barreto FC, Barreto DV, Liabeuf $S$, Meert N, Glorieux G, Temmar M, Choukroun G, Vanholder R, Massy ZA; European Uremic Toxin Work Group (EUTox): Serum indoxyl sulfate is associated with vascular disease and mortality in chronic kidney disease patients. Clin J Am Soc Nephrol 4: 1551-1558, 2009.

27) Sato B, Yoshikawa D, Ishii H, Kikuchi R, Arima T, Takeshita K, Inoue Y, Suzuki S, Tanaka M, Kumagai S, Matsumoto M, Hayashi M, Ando H, Amano T, Matsubara T, Niwa T, Murohara T: Indoxyl sulfate, a uremic toxin, and carotid intima-media thickness in patients with coronary artery disease. Int J Cardiol 163: 214-216, 2013.

28) Schroeder JC, Dinatale BC, Murray IA, Flaveny CA, Liu Q, Laurenzana EM, Lin JM, Strom SC, Omiecinski CJ, Amin S, Perdew GH: The uremic toxin 3-indoxyl sulfate is a potent endogenous agonist for the human aryl hydrocarbon receptor. Biochemistry 49: 393-400, 2010.

29) Chitalia VC, Shivanna S, Martorell J, Balcells M, Bosch I, Kolandaivelu K, Edelman ER: Uremic serum and solutes increase post-vascular interventional thrombotic risk through altered stability of smooth muscle cell tissue factor. Circulation 127: 365-376, 2013.

30) Gondouin B, Cerini C, Dou L, Sallee M, Duval-Sabatier A, Pletinck A, Calaf R, Lacroix R, Jourde-Chiche N, Poitevin S, Arnaud L, Vanholder R, Brunet P, Dignat-George F, Burtey S: Indolic uremic solutes increase tissue factor production in endothelial cells by the aryl hydrocarbon receptor pathway. Kidney Int 84: 733-744, 2013.

31) Yisireyili M, Saito S, Abudureyimu S, Adelibieke Y, Ng HY, Nishijima F, Takeshita K, Murohara T, Niwa T: Indoxyl sulfate-induced activation of (pro)renin receptor promotes cell proliferation and tissue factor expression in vascular smooth muscle cells. PLoS ONE 9: e109268, 2014. 